Article

\title{
Accountability through Environmental and Social Reporting by Wind Energy Sector Companies in Spain
}

\author{
José A. Moseñe Fierro ${ }^{1}$, M. Victoria Sanagustín-Fons ${ }^{1}$ (i) and César Álvarez Alonso ${ }^{2, *}$ (i) \\ 1 Faculty of Business and Public Management, University of Zaragoza, 22001 Huesca, Spain; \\ jamosene@unizar.es (J.A.M.F.); vitico@unizar.es (M.V.S.-F.) \\ 2 IE Law School, IE University, 28006 Madrid, Spain \\ * Correspondence: cesara@faculty.ie.edu
}

Received: 18 June 2020; Accepted: 5 August 2020; Published: 7 August 2020

\begin{abstract}
At present, energy transition is a crucial phenomenon that is at the very heart of governmental policies. There are a huge number of stakeholders involved in the change, but among these, the main socioeconomic actors that affect environmental and social impacts are energy companies. In this research, we analyze their institutionalized role in the Spanish wind energy sector, in the framework of the ecological movement. We consult the special views, opinions and motivations given by managers responsible for Institutional Relations in the main wind energy companies in Spain, and their perceptions of environmental reporting. We therefore tackle aspects related to the drivers of the social and environmental disclosure of environmental and social information. Research has been carried out based on documentary secondary analysis, and the use of a qualitative method with semi-structured interviews has revealed tendencies and pressures in the sector. Results suggest that the social context and public opinion pressure organizations to reveal environmental and social information. We also put forward how information is conveyed to the society through accountability practices, and the different institutionalized ways in which this is achieved.
\end{abstract}

Keywords: environmental and social reporting; new institutionalism in sociology; actor-centered institutionalism; Spanish wind energy; transparency; corporate social responsibility

\section{Introduction}

The so-called New Institutionalism in Sociology (NIS) theory, mainly based on the social theory of Parsons [1] and Selznick [2], is becoming one of the dominant approaches in the field of business behavior research. This theory has a wide degree of applicability; the main reason is that all organizations go through a process of institutionalization throughout their life span [3]. In this process, organizations must respond to social demands. DiMaggio and Powell [4] point out that the institutionalization process leads companies to assume the values of the society in which they find themselves, in a way that legitimizes their activity. Recent studies underline this concept, for instance, Jessop, Wilson, Bardecki and Searcy [5], proving that the so-called CED (Corporate Environmental Disclosure) of both the subsidiaries of multinational agrochemical corporations and domestic companies in India appears to underpin local concerns of legitimacy.

However, one of the criticisms of this theory is that it has focused on institutionalization more as a result $[6,7]$ than as a process; thus, the roles and powers of certain interest groups, and the presence and role of so-called social actors, have been neglected [8]. The NIS considers how organizations take into account social changes, pressures and different socioeconomic and sociocultural trends if they want to survive [9]. In this sense, the research performed by Fazzini and Dal Maso [10] shows that the practice of environmental voluntary disclosure represents value-relevant information, positively correlated with a firm's market value. Other researchers have focused on how transparency has become a very important 
management instrument [11], and how company managers' attitudes towards the environment and the stakeholders influence how the company communicates its actions to society, so as to achieve or maintain its social legitimacy [12]. Similarly, Pucheta-Martínez and López-Zamora [13] explore the engagement with stakeholders of certain Boards of Directors regarding environmental disclosure. Other authors try to go beyond, and indicate that stakeholders perceive different disclosure types and disclosure items as important to differing degrees. CSR reports provide more stakeholder-relevant social and environmental disclosure than annual reports [14].

Figure 1 shows all the elements of the environmental transitions in wind energy companies, and the main processes and actors involved.

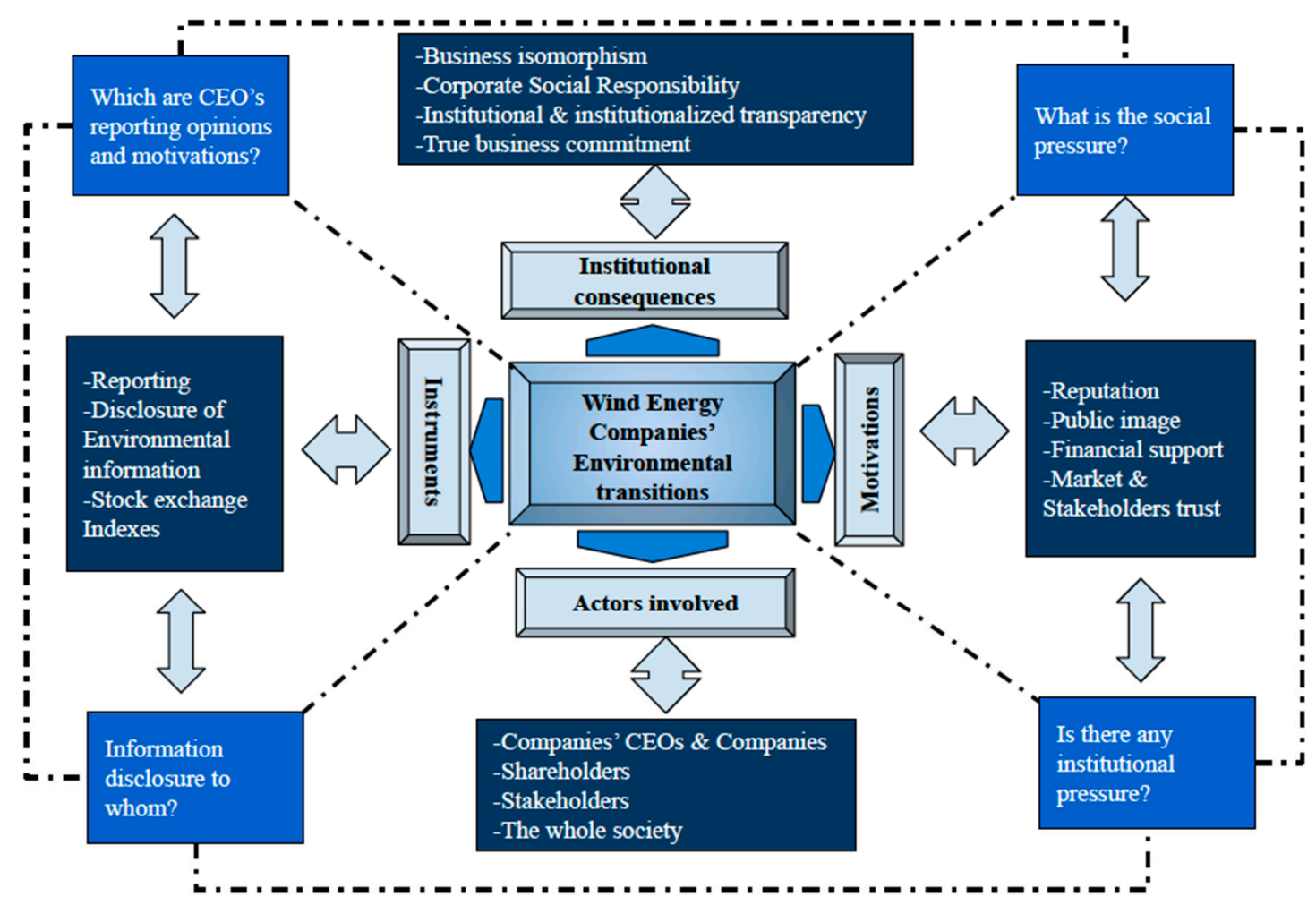

Figure 1. Wind energy companies' environmental transitions. Source: own elaboration.

The new actor-centered institutionalism is the theoretical framework for this research; it is based on the analysis model developed by Scharpf $[8,15]$. Figure 2 shows the different constituent elements of this model, such that the institutional environment (norms, rules, customs, etc.) defines the possibilities of action of the social actors (companies, entities, etc.), and their ways of interacting. The influence of this environment on the actors is not decisive, as Scharpf points out, since there is almost always a certain margin for them to choose between different strategies [15]. 


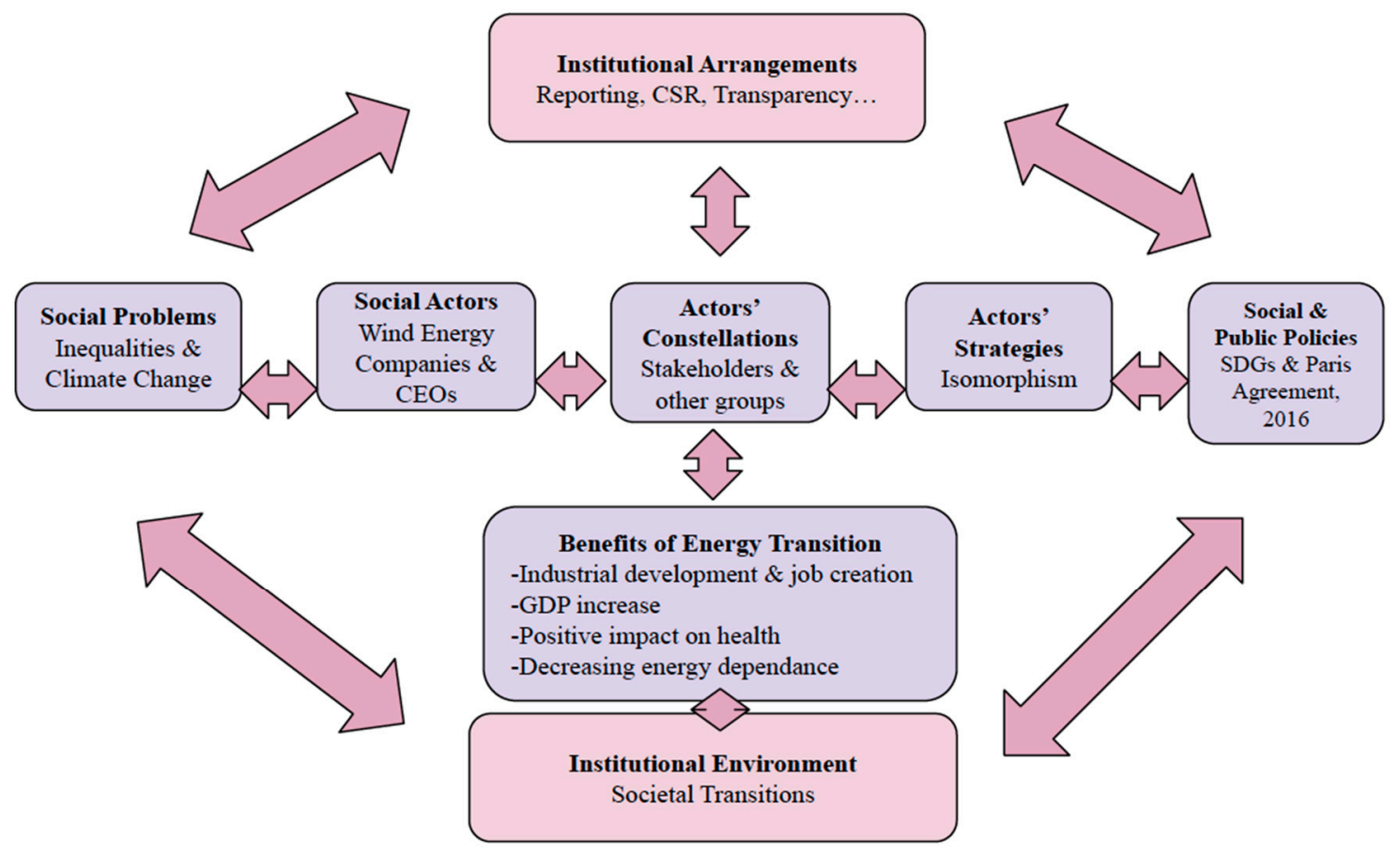

Figure 2. Actors, strategies and public policies. Source: partially adapted from Scharpf [16].

The institutional environment is characterized by public policies that have promoted sustainable development for years, as well as the commitment of the different social actors involved in it [17]. In this case, the identified social actors are the energy companies that are involved in the field of renewables, and whose environmental impact is high-but much less high than the traditional utilities [18,19]. In the case of wind energy, the impacts are basically the following: greenhouse gas (GHG) footprint during equipment manufacturing, noise pollution, flicker effect, visual interference and negative impacts on wildlife [20]. The institutional arrangements are illustrated by those instruments that the main organizations use to justify their correct actions, oriented towards achieving the Sustainable Development Goals (SDGs) [21]. Thus, environmental reporting is analyzed mainly, as a significant tool for completing the task in this sector. The interest in business sustainability is evident; more than 9600 companies in 168 countries have voluntarily signed the Global Compact of the United Nations [22].

The three-year study of KPMG in 2017, concerning corporate social responsibility information, indicated that each business sector has a reporting rate equal to or higher than $60 \%$ [23]; these data show the extent and generalization, among companies, of the disclosure of information concerning social, economic and environmental development. Regarding this aspect, Yusoff, Othman and Yatim [24] found real consistencies in the cultural dimensions of ENRP (Environmental Reporting Practices) in two countries (Malaysia and Australia), and the orientation of the practice across nations indicates a promising move towards the standardization and harmonization of successful implementations of environmental accounting and reporting. Even at the investor level, there are different stock indexes based on sustainability reporting that demonstrate responsibility in management, such as the DJSI (Dow Jones Sustainability Index), FTSE4 Good (Financial Times Stock Exchange for Good), KLD Global Climate 100, and S\&P Clean Energy (Standard and Poor's Clean Energy).

Society demands more than ever that companies make a contribution to sustainable growth in line with the SDGs established by the United Nations [25]. Companies are responding to these demands mainly through reporting everything [26]. Following Bocken [27], the road to a new economy should be a system that minimizes the consumption of energy and natural resources; a system wherein the social and environmental benefit is prioritized above the economic one; a system based on collaboration and not on competition. 
The originality of this paper lies in the fact that this kind of study has not been carried out to date in Spain. It is in line with the most recent developments in companies' policies, and looks for a more comprehensive approach that tackles social corporate responsibility in terms of energy transition. Society responds to what private companies do to achieve the objective of a carbon-neutral economy. Therefore, companies are more and more interested in responding to these requirements, as they are held accountable for their actions. The paper aims to show how managers provide information to stakeholders in relation to the company's environmental and social commitment. As a consequence, the paper draws attention to the fact that there is a specific social and environmental dimension that private companies must also focus on, instead of only focusing on their economic profit. Social benefit becomes paramount within the current energy transition process.

\section{Context}

Renewables in Spain accounted for $50.1 \%$ of the installed power in the country by the end of 2019, at 55,195 MW. Renewables-based electrification is a key instrument in accomplishing the decarbonization of Europe's economy and in struggling against climate change. Wind energy can, therefore, contribute to such a change. With roughly 26,000 MW of accumulated capacity, wind energy was the second largest source of electrical generation in Spain in early 2020 (Figure 3). Spain is the fifth country in the world in terms of installed wind power, after China, the US, Germany and India.

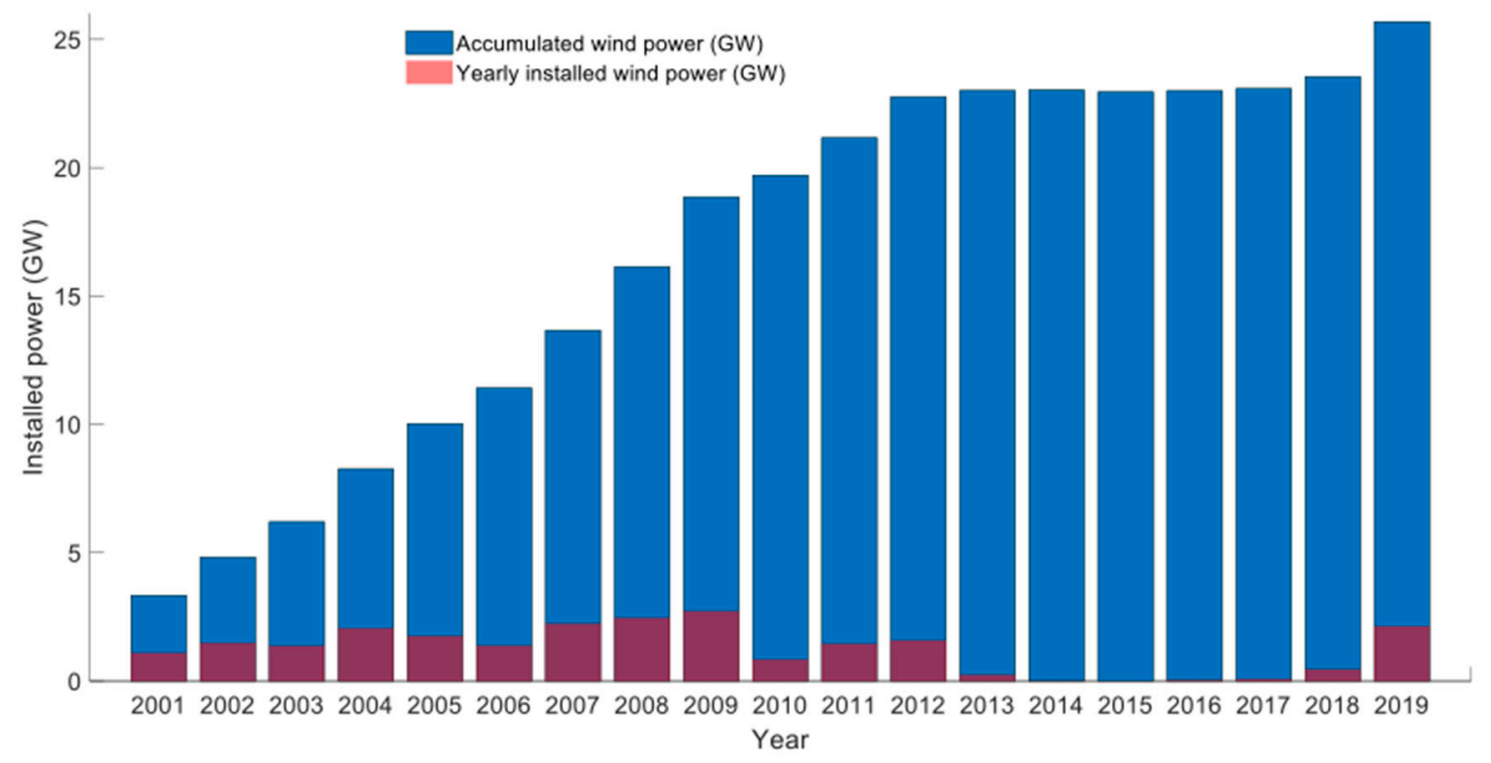

Figure 3. Yearly and accumulated installed wind power 2001-2019 in Spain. Source: Red Eléctrica de España (REE) [28].

The Spanish energy sector is highly dependent on the prices of energy commodities, which are increasing dramatically, something that is aggravated by the high degree of energy dependence which reaches $74 \%$ at the national level. The annual average price of a ton of coal has increased from EUR 53/t in 2016 to EUR 76/t in the first nine months of 2018, registering values close to EUR 85/t in the first days of October. The crude oil Brent has gone from USD 44/barrel in 2016 to USD 72/barrel in 2018, with prices close to USD 80/barrel in early October. Concerning emission trading, the price of one metric ton of carbon dioxide $\left(\mathrm{CO}_{2}\right)$ has gone from EUR 5 in 2016 to values above EUR 20 in 2018. Regarding gas prices, the European reference price (National Balance Point market) has increased from EUR 17/MWh in 2016 to EUR 24/MWh so far in 2018, with prices close to EUR 29/MWh in early October. As a result, the price of electricity in the Iberian wholesale market registered an average value of EUR 71.35/MWh in September 2018, approaching the maximum monthly historical value, which was reached in January 2006 with EUR 73.14/MWh. 
Under these unprecedented circumstances, the Spanish Government has approved a legal standard to accelerate energy transition through the deployment of renewables [29]. It has also developed a Strategic Framework for Energy that lays the foundations for the future Green Pact in Spain. The decarbonization objective set out in this framework entails the reduction of one out of every three tons of greenhouse gases emitted by Spain during the next decade. To this end, a firm commitment was made to renewables which, by 2030 , will account for more than $40 \%$ of final renewable energy, and more than $70 \%$ of electricity generation. Wind and photovoltaic technologies will increase their generation threefold, going from a total production of 63 TWh during 2019 to the $200 \mathrm{TWh}$ foreseen for 2030 by the National Integrated Energy and Climate Plan of the Ministry for Ecological Transition. This will require increasing the installed capacity of both technologies by an additional 54 GW by 2030 (24 GW of new wind capacity and 30 GW of new photovoltaic installations). This will also be possible thanks to the state of maturity of wind and photovoltaic technologies, which are already competitive at their current price levels on the wholesale electricity markets. Supply uncertainties due to turmoil, price volatility and huge costs are not just the main driver for investing in renewable energy. Severe environmental degradation, as well as the risks to human health [30], are behind the need for reducing fossil fuels. That said, fossil fuels are by far the largest sources of energy, and are widely projected to dominate the European energy mix until at least 2030 [31].

Renewables are going to play an important role in the ecological transition process in the EU [32]. Spain created in 2018 a Ministry for the Ecological Transition, a new structure that brings together the energy sector and environmental policy. According to Wind Europe [33]:

"renewables have played a central role in this transformation, with 298 GW added to the power sector since 1995. And wind energy has been the largest single contributor, with 182 GW of capacity installed as of the end of June 2018. Wind energy now accounts for $12 \%$ of Europe's electricity and renewables in total account for 30\%".

The sector is steadily growing, since the demand for wind energy continues to grow at an exponential rate, due to the reduction in operating and maintenance costs and the increasing reliability of wind turbines [34]. Approximately $75 \%$ of the annual downtime in wind turbines is caused by only $15 \%$ of the failures [35]. Furthermore, wind electricity production puts a downward pressure on the wholesale market price of electricity [36], as a result of two effects: (i) the direct effect of displacing the conventional technology, leading to lower electricity prices compared with the absence of wind generation; (ii) the indirect effect of the fact that wind electricity generation implies lower demand for conventional electricity, and therefore a reduction in the demand for $\mathrm{CO}_{2}$ allowances.

As stated by the Energy Roadmap 2050 delivered by the European Commission, people's well-being, industrial competitiveness and the overall functioning of society are dependent on safe, secure, sustainable and affordable energy [37]. This implies a great challenge for the power grid across the European Union. One of the most common challenges for wind energy as a renewable energy source (RES) is its impact on society. There are usually three dimensions of social acceptance, namely socio-political, community and market acceptance [38].

Social acceptance is increasingly important in determining the future of wind energy projects [39]. Although wind energy projects are extensively accepted by Spanish society, there are some drivers to social opposition, one of them being the presence of wind turbines that may potentially harm individuals living nearby, especially due to the visual impact and noise that these wind turbines cause [40]. The International Energy Agency (IEA) has also defined the concept of social acceptance of wind energy as "the societal consensus on the planning, construction, and operation of wind power projects that, therefore, has the potential to become a powerful facilitator of wind development" [41]. In general, megawatt-scale wind turbines connected to the distribution circuit are generally located away from heavily-populated areas, and therefore their impact affects mainly rural areas [42]. 


\section{Method}

The main objective of this research is to analyze the deep drivers of wind-energy companies towards the disclosure of their environmental commitment. The other two objectives are (i) to observe whether there is some kind of social pressure, and (ii) to determine whether the companies are immersed in an institutional environment that determines their environmental behavior in reporting. To achieve these objectives, we have consulted the companies' staff or the representatives that were provided.

This way, information is directly obtained from the managers responsible for reporting in the selected companies. We specially focused on relevant matters, such as who is the recipient of the given information, and what are the benefits of the information compared with the institutional discourse, posing the research question (RQ1): Who is environmental information in the Spanish energy sector prepared for? In addition to the data obtained in our research, the leading motivations of companies in terms voluntary disclosure have been analyzed via their responses to the research question (RQ2): Are there isomorphic tendencies that show a marked homogenization in the process of revealing environmental information? In the answer to the following, some information is obtained and validated (RQ3): Are there institutional pressures that influence and condition the behavior of companies in the sector?

The study adopts a mixed-method approach (descriptive, qualitative, and descriptive and inductive), including the following techniques: (i) systematic literature review (SLR) and (ii) semi-structured interviews $[43,44]$. The interviews were done with the managers responsible for the environmental departments of companies in the Spanish wind sector. In total, 20 deep semi-structured interviews were done; from there, we just focused on the narratives coming from the responsible staff that elaborate environmental information. We have focused on two companies: the largest one in the country, and the other with more international presence.

To ensure that the objectives were met in the interviews conducted, a guided interview was designed (Supplementary Materials) taking as reference a previous study performed by Moseñe et al. [45]. The reason for the interview was explained to interviewees, and the confidentiality of the treatment of the information offered was assured for them, which contributed to increasing our confidence in obtaining significant and relevant information [46].

Of the seven companies that constitute the total population under study (Spanish energy producers), two were selected in an evolutionary process in which the designated variables quickly reached their saturation. The first company, " $\mathrm{A}$ ", was selected due to its importance and because it constitutes a case that represents the majority, since it is one of the largest companies in our country and one with a market share of more $24.15 \%$ [47]. " $\mathrm{A}$ " is one of the leaders in the sector, determined by its position, volume, size, clients and internationalization. It makes use of its superiority in championing the disclosure of environmental information; it stands out for this, and accordingly generates a trend within the sector [45].

Company " $\mathrm{B}$ " has been selected because it is an outstanding case; this organization has an aggressive and expansive international strategy, and in a short time has become one of the most important corporations in the wind energy sector, providing $18.5 \%$ of the total wind energy production in 2018 [47]. It was integrated into a large industrial conglomerate and its good work in the field of environmental reporting has been disseminated to other areas of the organization. Within organizations, we chose the most accessible people willing to give relevant information [43]. Even though these two companies represent just $43 \%$ of the total market share, they are the only ones that reach shares higher than $10 \%$ in an atomized market [47], and it is because of this that we have made a relevant analysis based on these two companies. Grounded theory was applied to the narrative discourse coming from the interviews [48], and the results were processed through a content analysis of the texts obtained via transcription of the interviews carried out (coding, categorization, thematization). The study of these texts was hermeneutic, as regards the interpretative-comprehensive effort [49], as we were placed in a different situation concerning the observed social reality, certain latent meanings and the subjectivities freely expressed. The importance of qualitative research lies in the peculiarity and 
value of the informants' speech, as well as the free and spontaneous manifestation of their opinions, which allows an enriching methodological approach to the subject under investigation [50].

\section{Results and Discussion}

\subsection{Motivations for Environmental Reporting}

The results of the semi-structured interviews show the main reasons and motivations for environmental reporting, which are summarized in Figure 4.

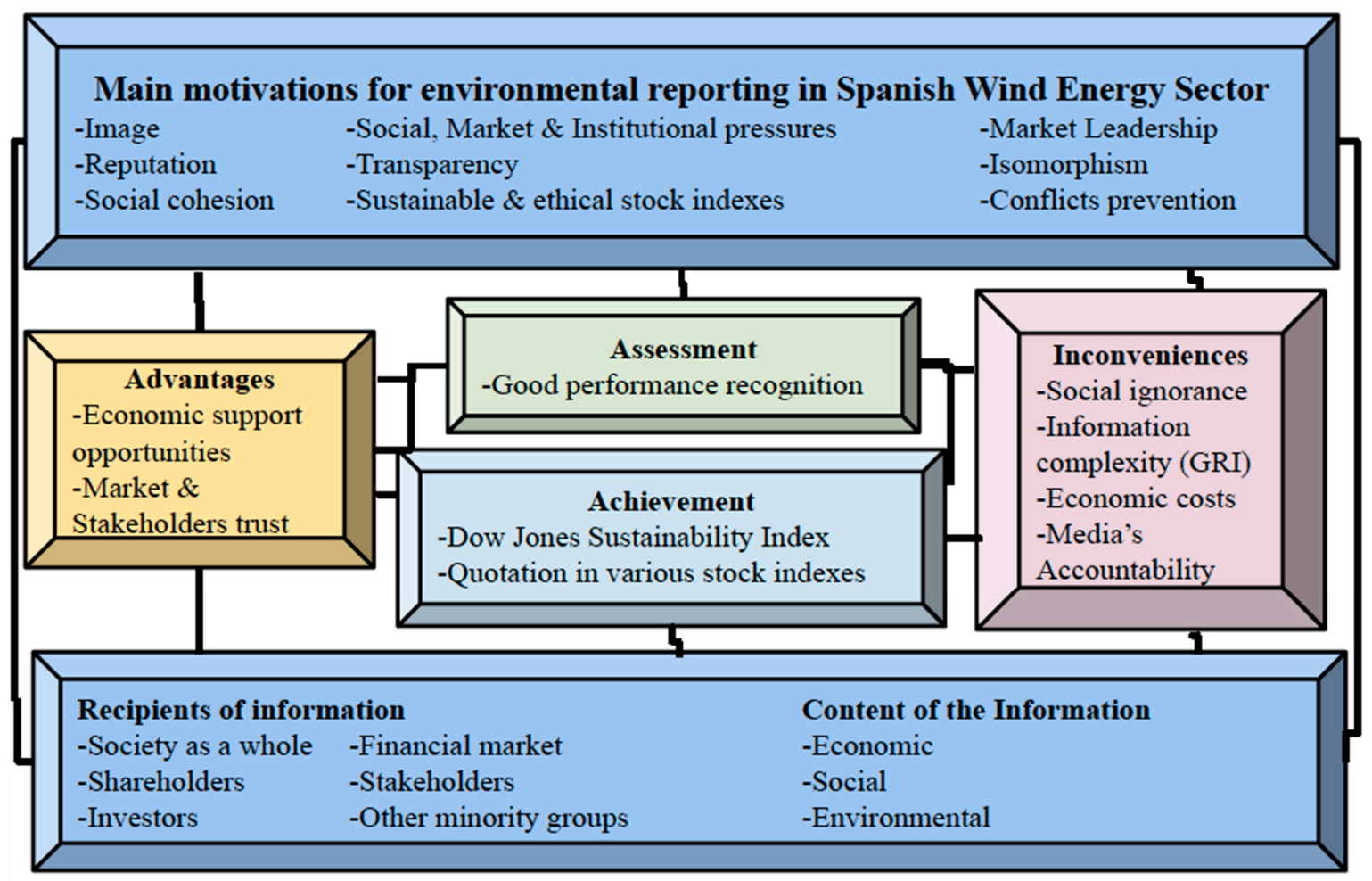

Figure 4. Main Reasons and motivations. Source: own elaboration.

\subsubsection{Motivations}

Exploring the driving motivations that lead organizations to disclose environmental information voluntarily has been the focus of numerous academic studies [51-54]. In this field, the temporal research that has been carried out since 1993 by KPMG, at three-year intervals [23], stands out. The answers provided by the interviewees are aligned with the image and prestige of the company, despite the fact that some arguments given in the official sustainability report were different [45]. On one hand, the largest and most consolidated company in the sector presents a more elaborated and deep discourse, mainly because of the time for which it has been in the sector and the pressure of leading the sector. On the other hand, the speech given explicitly by the head of company B points to the intention of reaching a greater social agreement and avoiding future problems.

\section{A: The main reason is transparency, it is considered as a sign of corporate identity and the environmental variable becomes a strategic element to create and promote improvement and innovation projects.}

B: To avoid future problems, to collect problems from all the groups involved and anticipate them. Reporting is essential. What it does not count, it does not exist. Prestige and status facilitate financing access and investment opportunities.

Both interviewees highlight the importance of doing things well and conveying the outcomes as an essential task for the company. This transparency increases opportunities to obtain financing for 
future investments [55-57]. Sustainability reports play an important role in this. All companies in the sector expressly mention in their sustainability reports their eagerness to contribute, or to continue their contribution to the DJSI: "With satisfaction, we can say that the fulfillment of our commitments regarding sustainability has been endorsed. DJSI has identified A as one of the leaders in its sector".

\subsubsection{Realization}

The interviewees showed different ways of dealing with their inclusion in an index that is publicly recognized. On the one hand, the leading and the veteran company consider being quoted the index as a corporate objective at the beginning, and later on, they try to obtain the full utility of the index. The other company takes advantage of the information and the work done on environmental information to enter into the index and to get special recognition by stakeholders.

\section{A: We believe that quoting in this prestigious index means achieving public recognition of the company's} commitment to sustainability within the international community of analysts and investors.

B: What we've done is what we disclose. But the objective is not to offer information to quote in DJSI. It is another public recognition for doing things well.

\subsubsection{Assessment}

Stock Markets have become one of the main factors in transparency and accountability. Several indexes, such as DJSI, FTSE4GOOD and KLD, have developed mechanisms aiming at ethical and sustainability-oriented investors [58]. Institutional investors can also be included in this group. In the speeches given by these organizations, constant references to these indexes appear, specifically to the DJSI, standing out with a preferential place. During the interviews, companies constantly stressed the effort made over time to be quoted in the index, and secondly to improve their score. This leads to the conclusion that there is pressure from the markets and the sector to be quoted in sustainable indexes [45]. The interviewees were asked about the perception of the benefits obtained from being quoted in this index:

A: It is a public recognition of the commitment to sustainability by the analysts and investors community. Our Co. has been in quoting since the beginning and in 2012 was chosen as the best one.

B: At the corporate level, campaigns are promoted to reinforce the image of the Company, as other companies also do. Decisions are taken at the corporate level and the image of taking advantage of the resources that were already available.

The answers given by the interviewees depict the normative pressure to remain among the best companies in the sector. The desire to quote in DJSI has created a trend in the sector, and the most veteran organization (A) points out that maintaining a leading position and the highest score possible in the index has become mandatory. The company with less experience in the sector (B) shows a clear tendency towards homogenization with other companies in the industry, confirming in this way a mimetic isomorphism.

\subsubsection{Advantages}

Quoting in the DJSI indicates that the criteria demanded to be quoted in this index have been reached by the company, which generates more confidence, since it seems that those companies quoting in the DJSI show an inclination towards more sustainable development [59]. According to this, it will be easier for them to receive financial support [60]. From an initial point, it seems to give the companies a competitive advantage, although it is difficult to maintain in the long term [61] since there is a tendency to imitate those behaviors considered successful in the industry [4]. The perception of being quoted in the prestigious index is quite different depending on the interviewees. This difference can be explained by the long-term benefits perceived by the companies $[59,62]$. The experience of quotation 
in the index, for 15 years in the case of the company more consolidated (A) and for only 6 in the other case (B), can justify the lack of concrete results in the medium term, as the interviewees state:

$\mathrm{A}:[\ldots]$ is an index that measures sustainability in the short and long term. Results influence investment decisions taken by investment managers. Internally, this evaluation provides quantitative indicators that allow the evolution of different areas to be monitored.

B: [ ... ] The image of the company has been reinforced and this translates into economic repercussions. Internally to inform the whole world about what is being done in the Company and to promote Benchmarking practices.

\subsubsection{Disadvantages}

Various research studies in this field confirm that one of the drawbacks of voluntary disclosure by companies is the cost that this practice implies [59,63-65]. Despite this, organizations continue doing this because they obtain benefits from this practice. In an investigation made by Delgado-Márquez, Pedauga and Cordón-Pozo [66], it is suggested that unregulated firms disclose-to cope with higher stakeholder pressure-more environmental information than firms operating in regulated environments. Additionally, a firm's international position positively influences its environmental disclosure, but it does negatively, and/or partially, moderate the relationship between industrial regulation of the sector in which the firm operates and such a firm's environmental disclosure. By the use of the information disclosed, users are able to make cross-sector comparisons [60], and see the evolution of each organization in the long term through their quotation in the DJSI, something that unfortunately is not always possible due to changes in the criteria [45].

In addition to these drawbacks, the interviewees claimed more recognition by society for their efforts, and the importance of the quotation in these sustainable indexes. Interviewees also appeal to the media to give a greater representation of these practices. This result contrasts with the conclusions of the analysis of the sustainability reports given by these companies, wherein media is not considered as a priority interest group for the companies [45], which fact is not aligned with the large firms' dependency on the media's accountability [67].

The companies' perceptions of the disclosure are not clear. The interviewees also point out the complexity of the information for the general public. This perception has been considered by the GRI as one of the main objectives indicated in the GRI preface [68]:

A: Needs media coverage, the general public is unaware of the importance of listing on this index.

B: [ ... ] It is not very clear at the internal level how this has impacted. Perhaps it is not enough to publish a lot of information, but it should be easily understandable.

\subsubsection{Recipients of the Information}

On this issue, the positions of the interviewees collude in pointing to financial markets as the main recipient $[69,70]$. Companies recognize that corporate disclosure is oriented mainly towards shareholders, analysts, investors and markets, which always place first. This perception helps to verify the instrumentalist approach that these companies take to corporate sustainability disclosure.

Indirectly and collaterally, other minority groups are mentioned as giving less attention to companies, since they are more unaware of this type of information. The leading company offers a more institutional discourse, focused on showing a faithful image of the company and the commitments assumed by it. Besides, financial information seems of be of greater relevance than environmental and social discourse, thus corroborating other research in this field $[60,62,70]$.

A: Formally, this information is addressed to the "interest groups" of the Company, because they are the ones interested in knowing the activities carried out by the company and their consequences, although, in practice, not all of them dedicate the same attention to it: currently, the most interested groups are investment analysts, with particular relevance to those who work with socially responsible investment. 
B: Outward, academics, investors, DJSI, and inward to inform the whole world of what is being done ... Fundamentally for the DJSI, investors, auditors, but at the user level, it is not clear ...

From the statements made by the interviewees, it is clear that the preparers of environmental information are aware that the different agents operating in financial markets, and those specifically listed, take environmental information into account in the decision-making process. Interest in environmental information is associated mainly with economic, labor and product aspects, leaving other kinds of interests, such as disclosures about their environmental performance to small investors and citizens, in the background.

\subsection{Contents of Environmental Information}

Environmental disclosure in organizations has been increasing in recent years, responding to societal demands. This does not necessarily imply a sustainable organization, this being a concept that it is impossible to define [71,72], but it should show the effort made by the company towards achieving a more sustainable model, in the framework of the SDGs. Both interviewees pointed out that social demands have been precisely what has prompted an increase in environmental information. This requirement has been generalized to other companies, the role of sustainability reporting being clear:

A: Currently, it is generally accepted that companies must take into account not only their economic results but also environmental and social impacts when carrying out their activities.

B: It is essential to collect and tell society what is being done in the company, what is not counted does not exist.

Organizations are aware of the growing importance of environmental information for society, and even though CSR revolves around the Triple Bottom Line (TBL) [73], as they reflect in their written reports and their institutional discourse, organizations place a greater weight on the economic aspects than on the social and environmental ones, which still have a long way to go. The use of GRI as a standard for environmental reporting influences companies' disclosure, since in addition to harmonizing and standardizing, the purpose of this guide is to empower social agents to require companies to be accountable [74]. The interviewees make allusions to the importance of economic aspects, with continuous references to markets, investors and financing, and they are fully aware, as they reflected in their statements, that environmental aspects are in second place for both society and the companies themselves.

A: It is generally accepted that companies must take into account their economic, environmental and social impacts when carrying out their activities, society demands that it should be explained how these impacts are being taken into account... We believe that the environmental and social dimensions are acquiring greater prominence and on the way to the relevance of relevance with financial information...

B: [ ... ] Doing things well has an economic answer behind ... Quoting in prestigious indexes is translated into economic advantages.

Reporting Standard

Regarding the format adopted to present the environmental information, the GRI standard (G4 version) has unquestionably been the one adopted by these companies. The responses of the interviewees confirm the adoption of this reference, because it has emerged as the leading set of guidelines among other voluntary environmental information systems [74], although this standard is not exempt from criticism $[45,72,75,76]$. The interviews show how the preparers echo some of the institutional innovations provided by the GRI, such as the inclusion of stakeholders, the evolution of the standard over time according to social demands, and the existence of an organizational guiding and 
guaranteeing the process [52]. The GRI also allows the comparison between different organizations [59], as well as the possibility of adding an external verification that increases its completeness and credibility $[77,78]$. The interviewees stressed the importance of the role of external verification as a tool for increasing the credibility of the information disclosed:

A: It is a well-valued international standard, it allows stakeholders to evaluate the progress done by companies in this field and it is compatible with independent external verification. It is a solid base to elaborate information with important attributes such as truthfulness and credibility. It reflects the commitment of the organization with the groups of interest.

B: [ ... ] It follows the same process that you have with the certifications, it's something voluntary. It is done because other companies in the sector are also doing it. The parameters are increasingly demanding, and if we can go ahead better. The GRI guidelines and standard has been chosen because it is the most worldwide recognized and used and it is easier to make comparison and verification ... To certify what I am doing and what I am proposing gives me an international acknowledgment.

The demand for environmental information is something that is constantly evolving, as has been stated before. There is a general pressure to comply with the norm in the sector, even if it is voluntary. This practice has become generalized in the sector, indicating in normative mimetic behavior. This proactive behavior of the leading organizations can make them the drivers of further standards [6].

A: Society demands that it should be explained how companies are taken into account its claims and public information is a good tool for this purpose.

B: It is reported because you have to do things well. The parameters are increasingly demanding, and if we can go ahead better for everybody. Sometimes minimums are set even in places where there is nothing. [ ... It It tries to respond to regulatory and compulsory requirements but it also goes further.

Regarding the importance to society of the activities carried out by the different organizations, both interviewees expressed their concern about responding to their stakeholders' demands. According to their institutional discourses, companies are fulfilling these demands, and their acknowledgment is reflected in the sustainability indexes [52,59,79].

Despite this, the interviewees refer to a lack of recognition from society of the work and effort done in terms of sustainability. They are improving, but they are also aware that they continue doing things wrong, and this is all some stakeholders see.

A: The awareness of the importance of promoting sustainable development has reached all areas of society. From NGOs, Public Administrations, clients, and society in general, more responsible behavior is demanded taking care of the environment and our organization has tried to respond to these demands of all its stakeholders.

B: What happens is that sometimes the effort made by the companies does not reach the knowledge of the people in the street. Especially if we are talking about large companies. In some cases, they can have their problems and people only realize about the problems and not with the good actions taken and the progress done.

\subsection{Economic-Financial Consequences of the Disclosure of Environmental Information}

The main benefits are the increasing transparency and the improving relationship with different stakeholders via the dissemination of sustainable information. Collateral issues arose, such as the controversial over-prices paid to the producers in the sector, which are threatened by budgetary restrictions in the country, and which have even questioned in some cases the viability of these renewable energies.

The sector is defending its commitment to providing clean energy for the future, which will make possible a reduction in the consumption of fossil fuels, and consequently the pollution derived from the 
use of them. The interviewees continue asserting their main point of view concerning clean renewable energies. They also defend the commitment to a cleaner energy system, in which there is still a long way to do to in gaining competitiveness and efficiency.

A: The emissions reduction is ratified with the commitment of the company for the use of the cleanest generation technologies, especially wind energy, considered today as the world leader among renewable energies. The effort done in this field has yielded us several awards in prestigious indexes.

B: The whole issue of investment in cleaner technologies has been a breakthrough. There will come a time when this energy will be much more mature. Over time it will occur even more efficiently.

The perception of the real utility of the environmental disclosure by these companies has been questioned from the beginning, although the interviewees do defend its utility, referring to it as a competitive advantage in the process of accessing markets, where good performance is recognized. They also indicate the role played by these organizations in the process of extending this type of informative practice to their customers, workers and, above all suppliers, achieving a dissemination of this information that reaches the general public.

A: We believe that the dissemination of environmental information promotes knowledge about environmental issues and a tendency to multiply the interest in these matters, so those concepts that were previously ready just for experts now are already part of the baggage of general society.

B: Showing the efficiency generated is very useful. It is an advantage in market competitiveness, where obtaining economic results doing things well is essential. When it comes to seeking support and funding it is essential to tell what is done.

Regarding the relationship between economic results and responsible behavior, several academic works have addressed this issue in both the short and long term. Several studies indicate that in the short term, there is excessive pre-eminence for economic aspects [56,80-82]. However, in the long term, the pre-eminence of economic results loses weight in favor of more responsible performance [56,83], even in times of crisis [84].

Society punishes behaviors considered irresponsible, and rewards activities carried out responsibly, as they are perceived as a less risky use of the mechanisms the company has for this purpose, such as the market and governments. The interviewees point to a higher level of responsibility in business activities, and while economic results prevail, ethical minimums must be respected at all costs.

A: It has reached a level of demand from which there is no going back regardless of the economic cycle in which we have to carry out our business. Environmental and social requirements are reaching the same relevance as the economic ones.

B: Accessing financing is increasingly being more difficult and is more demanding in environmental issues. This reinforces responsible behaviors on the part of the companies and encourages them to continue working in that line although getting money is becoming more and more complicated.

\section{Conclusions and Policy Implications}

Companies reveal environmental information to increase transparency, and to show that they behave responsibly within the society in which they accomplish their activities. Despite the efforts made by the organizations to improve the information provided, there is still a long way to go until the environmental information is equated in importance with economic information. The ecological transition of energy companies, whose environmental impact is high, is still slow, and must move forward so as to achieve the essential improvement, but none of the analyzed corporations focus on this issue.

Reporting practices seem to be driven by the fact that there is a perception that brings benefits to organizations, especially in financial matters and in the long term. These companies and their 
representatives are fully aware that agreements reached by consensus with all involved and concerned stakeholders avoid future problems. Companies achieved this type of informative practice by following the example of other successful organizations, due to the pressure exerted in the sector. This results in a common practice that is widespread in the Spanish energy sector. In addition to the pressure to be adapted to the norm, there is competition to attain and maintain a position of leadership. Maintaining the referred leadership is perceived and wielded as being like a letter of recommendation in stock markets, where the competition to attract resources from investors, workers and consumers is fierce.

Investors and shareholders are the main interest group for which environmental information is intended, and the impact on the company is clear in the form of financial support. The degree of conciseness in the user groups is much greater when referring to the financial groups than when referring to other groups. The lack of identification of other recipients means that the information offered is not as clear, transparent and useful as was expected. Environmental and social information seems to be aimed at those financial stakeholders that can support the companies. The general public, represented by citizens or even the media, is not really considered as the important recipient of the information. Policymakers should be concerned about the possibilities of renewable energy, especially in a high external energy-dependent country like Spain. Besides, environmental and social aspects should be taken into account, and consequently a clear policy should be adopted to promote renewable energy and make companies report their environmental and social impacts.

Although environmental information still appears to be in second place with respect to financial information, it is gaining importance gradually. It is necessary to disseminate this type of information, as well as make it more accessible and interpretable by the general public. The demand for environmental information, and the transition to a more ecological system, are growing, and there is evidence that these processes will not reverse. The study carried out reflects a limited number of companies. Still, they represent almost $50 \%$ of the sector in Spain. In any case, this study advances the knowledge in the field as there was a lack of research tackling the issue in this sector. To tackle a more encompassing representation of the sector, it is necessary to follow through with more interviews, since the sector remains fragmented. That may be the object of future research work. Another further line of research would be oriented towards the real perception of the recipients of the environmental information, especially those groups considered less important as a society: ecologists, NGOs or public administrations. In this way, the main actors involved in the communication process will have been studied, as will the appropriateness of the communication channel used for this purpose.

Supplementary Materials: The following are available online at http://www.mdpi.com/2071-1050/12/16/6375/s1, Semi-Structured Interview Script.

Author Contributions: J.A.M.F., M.V.S.-F. and C.Á.A. have pointed out the research topic, research objectives and the theoretical perspective and have been writing-original draft preparation, writing-review and editing; J.A.M.F. has proposed the design of the research, the main aspects of the study and has been looking for the relevant informants to carry out the field work; M.V.S.-F. has developed the theoretical conceptualization of the study; C.Á.A. has worked with the qualitative method and data analysis, discussion and conclusions. All authors have read and agreed to the published version of the manuscript.

Funding: This study was co-financed by the Regional Government of Aragon, Spain, in the framework of the Research Group Ref. S33_17R.

Acknowledgments: Special thanks for the support of the Regional Government of Aragon, Spain.

Conflicts of Interest: The authors declare no conflict of interest.

\section{References}

1. Parsons, T. El Sistema Social; Alianza Editorial: Madrid, Spain, 1951.

2. Sutton, F.X.; Selznick, P. Leadership in Administration: A Sociological Interpretation. Am. Sociol. Rev. 1958, 23, 98. [CrossRef]

3. Scott, W.R.; Christensen, S. In the Institutional Construction of Organizations: International and Longitudinal Studies; Sage: Thousand Oaks, CA, USA, 1995. 
4. DiMaggio, P.; Powell, W.W. The Iron Cage Revisited: Institutional Isomorphism and Collective Rationality in Organizational Fields. Am. Sociol. Rev. 1983, 48, 147. [CrossRef]

5. Jessop, A.; Wilson, N.; Bardecki, M.; Searcy, C. Corporate Environmental Disclosure in India: An Analysis of Multinational and Domestic Agrochemical Corporations. Sustainability 2019, 11, 4843. [CrossRef]

6. DiMaggio, P.J.; Powell, W. The New Institutionalism in Organizational Análisis; Powell, W., DiMaggio, P.J., Eds.; University of Chicago Press: Chicago, IL, USA, 1991.

7. Zucker, L.G. Institutional theories of organizations. Annu. Rev. Sociol. 1987, 13, 443-464.

8. Scharpf, F.W. Institutions in Comparative Policy Research. Comp. Polit. Stud. 2000, 33, 762-790. [CrossRef]

9. Sanz-Hernández, A.; Sanagustín-Fons, M.V.; Rodríguez, M.E.L. A transition to an innovative and inclusive bioeconomy in Aragon, Spain. Environ. Innov. Soc. Transit. 2019, 33, 301-316. [CrossRef]

10. Fazzini, M.; Maso, L.D. The value relevance of "assured" environmental disclosure. Sustain. Account. Manag. Policy J. 2016, 7, 225-245. [CrossRef]

11. Mason, M. Transparency for Whom? Information Disclosure and Power in Global Environmental Governance. Glob. Environ. Politics 2008, 8, 8-13. [CrossRef]

12. Cormier, D.; Gordon, I.M.; Magnan, M. Corporate environmental disclosure: Contrasting management's perceptions with reality. J. Bus. Ethics 2004, 49, 143-165.

13. Pucheta-Martínez, M.C.; López-Zamora, B. Engagement of directors representing institutional investors on environmental disclosure. Corp. Soc. Responsib. Environ. Manag. 2018, 25, 1108-1120. [CrossRef]

14. Lu, Y.; Abeysekera, I. What Do Stakeholders Care About? Investigating Corporate Social and Environmental Disclosure in China. J. Bus. Ethics 2015, 144, 169-184. [CrossRef]

15. Scharpf, F.W. Games Real Actors: Actor-Centered Institutionalism in Policy Research; Routledge: New York, NY, USA, 1997.

16. Scharpf, F.W. Games Real Actors Play: Actor-Centered Institutionalism in Policy Research; Routledge: New York, NY, USA, 2018.

17. De Aguiar, T.R.; Fearfull, A.; Sanagustín-Fons, M.V. Calculating the carbon footprint: Implications for governing emissions and gender relations. Account. Forum 2016, 40, 63-77. [CrossRef]

18. Brown, M.T.; Ulgiati, S. Emergy evaluations and environmental loading of electricity production systems. J. Clean. Prod. 2002, 10, 321-334. [CrossRef]

19. Kim, S.-H. Evaluation of negative environmental impacts of electricity generation: Neoclassical and institutional approaches. Energy Policy 2007, 35, 413-423. [CrossRef]

20. Saidur, R.; Rahim, N.A.; Islam, R.; Solangi, K.H. Environmental impact of wind energy. Renew. Sustain. Energy Rev. 2011, 15, 2423-2430. [CrossRef]

21. Bebbington, J.; Unerman, J.; Parker, L. Achieving the United Nations Sustainable Development Goals: An enabling role for accounting research. Account. Audit. Account. J. 2018, 31, 2-24. [CrossRef]

22. United Nations Global Compact (UNGC). The SAGE Encyclopedia of Business Ethics and Society; SAGE Publications, Inc.: Thousand Oaks, CA, USA, 2018.

23. KPMG. El Camino por Recorrer. Estudio KPMG sobre Reporting de Responsabilidad Corporativa 2017; Resumen ejecutivo con datos de España; KPMG International: Amstelveen, The Netherlands, 2017.

24. Yusoff, H.; Othman, R.; Yatim, N. Culture and Accountants' Perceptions of Environmental Reporting Practice. Bus. Strat. Environ. 2013, 23, 433-446. [CrossRef]

25. United Nations. Transforming Our World: The 2030 Agenda for Sustainable Development. 2015. Available online: https://sustainabledevelopment.un.org/sdgs (accessed on 15 January 2019).

26. Starik, M.; Kanashiro, P. Toward a Theory of Sustainability Management. Organ. Environ. 2013, 26, 7-30. [CrossRef]

27. Bocken, N.; Short, S.; Rana, P.; Evans, S. A literature and practice review to develop sustainable business model archetypes. J. Clean. Prod. 2014, 65, 42-56. [CrossRef]

28. Red Eléctrica Española. Las Energías Renovables en el Sistema Eléctrico Español; REE: Madrid, Spain, 2017 ; p. 2.

29. Miguel, G.S.; Del Río, P.; Hernández, F. An update of Spanish renewable energy policy and achievements in a low carbon context. J. Renew. Sustain. Energy 2010, 2, 31007. [CrossRef]

30. Payan, M.B.; Roldan-Fernandez, J.M.; Garcia, A.L.T.; Bermúdez-Ríos, J.M.; Riquelme-Santos, J.M. Costs and benefits of the renewable production of electricity in Spain. Energy Policy 2013, 56, 259-270. [CrossRef]

31. Pedraza, J.M. Electrical Energy Generation in Europe The Current and Future Role of Conventional Energy Sources in the Regional Generation of Electricity; Springer: Berlin/Heidelberg, Germany, 2015; p. 3. [CrossRef] 
32. Jacobs, D. Renewable Energy Policy Convergence in the EU: The Evolution of Feed-in Tariffs in Germany, Spain and France; Routledge: London, UK, 2016.

33. Wind Europe. Wind Energy in Europe in 2018. Trends and Statistics. 2018. Available online: https: //windeurope.org/about-wind/statistics/ (accessed on 10 January 2020).

34. Muñoz, C.Q.G.; García Márquez, F.P. “Wind Energy Power Prospective”. In Renewable Energies. Business Outlook 2050; Springer International Publishing AG: Berlin/Heidelberg, Germany, 2018; p. 83. [CrossRef]

35. Fischer, K.; Besnard, F.; Bertling, L. Reliability-Centered Maintenance for Wind Turbines Based on Statistical Analysis and Practical Experience. IEEE Trans. Energy Convers. 2012, 27, 184-195. [CrossRef]

36. Saenz De Miera, G.S.; González, P.D.R.; Vizcaíno, I. Analysing the impact of renewable electricity support schemes on power prices: The case of wind electricity in Spain. Energy Policy 2008, 36, 3345-3359. [CrossRef]

37. European Commission. Energy Roadmap 2050; Publications Office of the European Union: Luxembourg, 2012.

38. Wustenhagen, R.; Wolsink, M.; Bürer, M.J. Social acceptance of renewable energy innovation: An introduction to the concept. Energy Policy 2007, 35, 2683-2691. [CrossRef]

39. Kardooni, R.; Yusoff, S.; Kari, F.B. Renewable energy technology acceptance in Peninsular Malaysia. Energy Policy 2016, 88, 1-10. [CrossRef]

40. Buritt, R.L.; Lehman, G. The body shop windfarm-an analysis of accountability and ethics. Br. Account. Rev. 1995, 27, 167-186.

41. IEA Wind. Social Acceptance of Wind Energy Projects Expert Group Summary on Recommended Practices. 2013. Available online: https://community.ieawind.org/search?executeSearch=true\&SearchTerm=task+28\& 1=1: (accessed on 28 December 2019).

42. Allen, A.; Zhang, Y.; Hodge, B.-M. Impact of Increasing Distributed Wind Power and Wind Turbine Siting on Rural Distribution Feeder Voltage Profiles. In Proceedings of the International Workshop on Large-Scale Integration of Wind Power into Power Systems as Well as on Transmission Networks for Offshore Wind Power Plants, London, UK, 22-24 October 2013.

43. Ruiz Olabuenaga, J.I. Metodología de la Investigación Cualitativa; Deusto: Bilbao, Spain, 2003.

44. Taylor, S.; Bogdan, R. Introducción a los Métodos Cualitativos de Investigación; Paidós: Barcelona, Spain, 1984.

45. Moseñe, J.A.; Burritt, R.L.; Sanagustín-Fons, M.V.; Moneva, J.M.; Tingey-Holyoak, J. Environmental reporting in the Spanish wind energy sector: An institutional view. J. Clean. Prod. 2013, 40, 199-211. [CrossRef]

46. Vallés, M. Técnicas Cualitativas de Investigación Social. Reflexión Metodológica y Práctica Profesional; Síntesis: Madrid, Spain, 1997.

47. Asociación Empresarial Eólica. Informe Annual 2018. Available online: https://www.aeeolica.org/anuario/ 2018/ (accessed on 12 January 2019).

48. Mattley, C.; Strauss, A.; Corbin, J. Grounded Theory in Practice. Contemp. Sociol. A J. Rev. 1999, $28,489$. [CrossRef]

49. Cárcamo, H. Hermenéutica y Análisis Cualitativo. Rev. Epistemol. Cienc. Soc. 2005, 23, 204-216.

50. Blanco-Gregory, R.; Martínez-Quintana, V.; Sanagustín-Fons, M.V. Microemprendimientos en agricultura ecológica y mercado slow food. RIO Int. J. Organ. 2020, 24, 159. [CrossRef]

51. Archel, P.; Lizarraga, F. Algunos determinantes de la información medioambiental divulgada por las empresas españolas cotizadas. Rev. Contab. 2001, 4, 129-153.

52. Brown, H.S.; De Jong, M.; Levy, D.L. Building institutions based on information disclosure: Lessons from GRI's sustainability reporting. J. Clean. Prod. 2009, 17, 571-580. [CrossRef]

53. Hackston, D.; Milne, M. Some determinants of social and environmental disclosures in New Zealand companies. Accounting, Audit. Account. J. 1996, 9, 77-108. [CrossRef]

54. García-Ayuso, M.; Larrinaga, C. Environmental Disclosure in Spain: Corporate Characteristics and Media Exposure. Rev. Esp. Financ. Contab. 2003, 32, 184-214. [CrossRef]

55. Deegan, C. Environmental disclosures and share prices-A discussion about efforts to study this relationship. Account. Forum 2004, 28, 87-97. [CrossRef]

56. Lorraine, N.; Collison, D.; Power, D. An analysis of the stock market impact of environmental performance information. Account. Forum 2004, 28, 7-26. [CrossRef]

57. Gupta, S.; Goldar, B. Do stock markets penalize environment-unfriendly behaviour? evidence from India. Ecol. Econ. 2005, 52, 81-95. [CrossRef] 
58. Correa, C.; Moneva, J.M. Contabilidad e información sobre responsabilidad social en tiempos de recesión/crisis de sostenibilidad. Span. Account. Rev. 2011, 14, 187-211. [CrossRef]

59. Logsdon, J.M.; Wood, D.J. Global Business Citizenship and Voluntary Codes of Ethical Conduct. J. Bus. Ethics 2005, 59, 55-67. [CrossRef]

60. Lozano, R.; Huisingh, D. Inter-linking issues and dimensions in sustainability reporting. J. Clean. Prod. 2011, 19, 99-107. [CrossRef]

61. Logsdon, J.M. Global Business Citizenship: Applications to Environmental Issues. Bus. Soc. Rev. 2004, 109, 67-87. [CrossRef]

62. Kolk, A. Sustainability, accountability and corporate governance: Exploring multinationals' reporting practices. Bus. Strat. Environ. 2007, 17, 1-15. [CrossRef]

63. Deegan, C.; Rankin, M. The materiality of environmental information to users of annual reports. Accounting, Audit. Account. J. 1997, 10, 562-583. [CrossRef]

64. Hughes, K.E. The Value Relevance of Nonfinancial Measures of Air Pollution in the Electric Utility Industry. Account. Rev. 2000, 75, 209-228. [CrossRef]

65. Mahapatra, S. Investor Reaction to a Corporate Social Accounting. J. Bus. Financ. Account. 1984, 11, $29-40$. [CrossRef]

66. Delgado-Márquez, B.L.; Pedauga, L.E.; Cordón-Pozo, E. Industries Regulation and Firm Environmental Disclosure: A Stakeholders' Perspective on the Importance of Legitimation and International Activities. Organ. Environ. 2015, 30, 103-121. [CrossRef]

67. Voinea, C.L.; Van Kranenburg, H. Media Influence and Firms Behaviour: A Stakeholder Management Perspective. Int. Bus. Res. 2017, 10, 23. [CrossRef]

68. Global Reporting Initiative. G4 Development. Full Survey Report; Global Reporting Initiative: Amsterdam, The Netherlands, 2012.

69. Freeman, R.E.; Reed, D.L. Stockholders and Stakeholders: A New Perspective on Corporate Governance. Calif. Manag. Rev. 1983, 25, 88-106. [CrossRef]

70. Onkila, T. Multiple forms of stakeholder interaction in environmental management: Business arguments regarding differences in stakeholder relationships. Bus. Strat. Environ. 2010, 20, 379-393. [CrossRef]

71. Burritt, R.L.; Schaltegger, S. Sustainability accounting and reporting: Fad or trend? Account. Audit. Account. J. 2010, 23, 829-846. [CrossRef]

72. Gray, R.; Milne, M.J. Sustainability reporting: Who's kidding whom? Chartered Account. J. N. Z. 2005, 81, 66-70.

73. Elkington, J. Towards the Sustainable Corporation: Win-Win-Win Business Strategies for Sustainable Development. Calif. Manag. Rev. 1994, 36, 90-100. [CrossRef]

74. Brown, H.S.; De Jong, M.; Lessidrenska, T. The rise of the global reporting initiative (GRI) as a case of institutional entrepreneurship. Corp. Soc. Responsib. Initiat. Work. Pap. 2007, 18, 36. [CrossRef]

75. Moneva, J.M.; Archel, P.; Correa, C. GRI and the camouflaging of corporate unsustainability. Account. Forum 2006, 30, 121-137. [CrossRef]

76. Newton, A. GRI reporters; who's fooling whom? Ethical Corp. Mag. 2004, 5, 44-47.

77. Adams, C.A.; Evans, R. Accountability, Completeness, Credibility and the Audit Expectations Gap. J. Corp. Citizsh. 2004, 2004, 97-115. [CrossRef]

78. Moneva, J.M. Mecanismos de verificación de la información sobre responsabilidad social corporativa. Papeles de Economía Española 2006, 108, 75-90.

79. Gustafsson, V.; My, J. A study of Environmental Disclosure within the OMXS30: With reference to the Global Reporting Initiative. Master's Thesis, Jönköping University, Jönköping, Sweden, 2017.

80. Blacconiere, W.G.; Patten, D.M. Environmental disclosures, regulatory costs, and changes in firm value. J. Account. Econ. 1994, 18, 357-377. [CrossRef]

81. Chan, C.C.C.; Milne, M. Investor reactions to corporate environmental saints and sinners: An experimental analysis. Account. Bus. Res. 1999, 29, 265-279. [CrossRef]

82. Spicer, B.H. Market Risk, Accounting Data and Companies'Pollution Control Records. J. Bus. Financ. Account. 1978, 5, 67-83. [CrossRef] 
83. Werther, W.B.; Chandler, D. Strategic corporate social responsibility as global brand insurance. Bus. Horizons 2005, 48, 317-324. [CrossRef]

84. Ortas, E.; Moseñe, J.A. Sustainability in times of crisis. A bet to failure or an up and coming value? evidence from the Spanish energy sector. Span. Account. Rev. 2011, 14, 299-320.

(C) 2020 by the authors. Licensee MDPI, Basel, Switzerland. This article is an open access article distributed under the terms and conditions of the Creative Commons Attribution (CC BY) license (http://creativecommons.org/licenses/by/4.0/). 